ЦИВІЛЬНЕ ПРАВО І ЦИВІЛЬНИЙ ПРОЦЕС;

СІМЕЙНЕ ПРАВО; МІЖНАРОДНЕ ПРИВАТНЕ ПРАВО

УДК 347.1

DOI https://doi.org/10.32844/2618-1258.2019.5-1.7

БАНАСЕВИЧ I.I.

\title{
ЕЛЕМЕНТИ ЦИВІЛЬНО-ПРАВОВОГО СТАТУСУ СПОЖИВАЧА
}

Наукову статтю присвячено питанню правового статусу споживача як учасника цивільних правовідносин та його елементам. Метою статті є здійснення теоретико-правового аналізу поняття «правовий статус споживача» як учасника цивільних правовідносин, а також дослідження його елементів на основі наукових досягнень цивілістики і правових позицій судових органів. У статті встановлено, що споживач - це фізична особа, в тому числі фізична особа-підприємець, яка придбаває (набуває іншим чином у власність або у користування) чи замовляє товари (роботи, послуги) або має намір придбати (набути іншим чином у власність або користування) чи замовити товари (роботи, послуги) для особистих або інших потреб, непов'язаних із підприємницькою діяльністю. Правовідносини, в яких споживач бере безпосередню участь, $\epsilon$ «цивільними правовідносинами за участю споживача».

Обгрунтовано, що споживачеві як учаснику цивільних правовідносин притаманний спеціальний правовий статус, який є проявом загального цивільно-правового статусу фізичної особи. У статті наведено авторську дефініцію поняття «спеціальний правовий статус споживача», під яким пропоновано розуміти сукупність прав та обов'язків, які закріплені законодавством про захист прав споживачів, а також гарантій здійснення цих прав шляхом встановлення особливого цивільно-правового механізму їх захисту. Доведено, що сутність спеціального правового статусу споживача полягає саме в доповненні чи конкретизації прав та обов'язків, що зумовлено наявністю в особи специфічних рис ії становища в суспільстві.

Проаналізовано загальні (універсальні) права та обов'язки споживача, які виступають елементами його спеціального правового статусу. Зроблено висновок про відсутність у споживача спеціальної правосуб'єктності (спеціальної правоздатності та спеціальної дієздатності), оскільки спеціальний правовий статус служить доповненням до загального цивільно-правового статусу фізичної особи, а не обмежує його.

При цьому проведено аналіз сучасних цивілістичних наукових досліджень, а також положень чинного законодавства України.

Ключові слова: споживач, правовий статус, спеціальний правовий статус споживача, права споживача, обов 'язки споживача, правосуб'єктність споживача.

The scientific article is devoted to the question of the legal status of the consumer as a participant of civil legal relations and elements of this status. The purpose of the article is to carry out a theoretical and legal analysis of the concept of "legal status of the consumer" as a participant of civil legal relations, as well as to study its elements based on scientific achievements in civil law and the legal positions of the judiciary as well as to study the features of its legal status as a participant of civil relations. The article establishes that the consumer is an individual, including an entrepreneur, who purchases (otherwise acquires ownership or use) or orders goods (works, services) or intends to

(C) БАНАСЕВИЧ І.І. - кандидат юридичних наук, доцент, доцент кафедри цивільного права (ДВНЗ «Прикарпатський національний університет імені Василя Стефаника») 
purchase (otherwise acquires or own), use or order goods (works, services) for personal or other non-business purposes. The legal relationships in which the consumer is directly involved are "civil legal relationships involving the consumer".

It is substantiated that the consumer as a participant of civil legal relations has a special legal status, which is a manifestation of the general civil legal status of an individual. The article gives the author's definition of the term "special legal status of the consumer". Which has to be understood as the set of rights and obligations enshrined in consumer protection legislation, as well as guarantees for the exercise of these rights by establishing a specific civil legal mechanism for their protection. It is proved that the essence of the special legal status of the consumer is precisely to supplement or specify the rights and obligations, which are conditioned by the presence of specific features of his position in society. The general (universal) rights and obligations of the consumer, which are elements of his special legal status, are analyzed. It is concluded that the consumer lacks a special legal personality (special legal capacity and special capacity), since the special legal status serves as a supplement to the general civil legal status of an individual, and does not limit it.

At the same time, the analysis of modern civil law scientific researches as well as the provisions of the current legislation of Ukraine was carried out.

Key words: consumer, legal status, special legal status of the consumer, consumer rights, consumer obligations, legal personality of the consumer.

Вступ. Правові перетворення в Україні, які розпочалися на початку 90-х років, вперше торкнулися однієї з найбільших груп суспільних відносин, які склалися на ринку товарів, робіт і послуг, - відносин за участю споживачів. Перехід до ринкової економіки зумовив гостру необхідність у чіткому правовому регулюванні відносин, які виникають між споживачами та суб'єктами підприємницької діяльності.

Після прийняття 12 травня 1991 р. Закону України «Про захист прав споживачів» [1] споживачі вперше отримали можливість застосувати законні способи захисту порушених прав. Із часом під впливом правозастосування, а також необхідності адаптації законодавства у сфері захисту прав споживачів до європейських стандартів інститут захисту прав споживачів зазнав докорінних змін. Однак, незважаючи на це, через відсутність механізмів реалізації більшість проголошених прав залишились декларативними.

Чинне нормативно-правове регулювання правовідносин за участю споживачів не гарантує якість та ефективність захисту прав споживачів на ринку товарів та послуг. Це, насамперед, стосується прогалин у Законі України «Про захист прав споживачів», що істотно впливають на рівень захисту прав споживачів. Так, у ньому не отримали свого остаточного вирішення такі основоположні питання, як точність легальних дефініцій «споживач», «споживчий договір», «права споживача»; недостатньо врегульовані такі важливі способи захисту, як неустойка та відшкодування моральної шкоди та ін. Також суперечливими $є$ наукові позиції про місце споживача серед суб'єктів права, визначення його правового статусу.

Окремі аспекти захисту прав споживачів та правовий статус споживача як учасника цивільних правовідносин були у сфері наукових інтересів таких вчених: М.М. Гудима [2], Г.А. Осетинська [3], Ю.Ю. Рябченко [4], О.Ю. Черняк [5], О.Ю. Сгоричева [6], Г.О. Ільченко [7], У.П. Гришко [8] та інших.

Постановка завдання. Метою статті є здійснити теоретико-правовий аналіз поняття «правовий статус споживача» як учасника цивільних правовідносин, а також дослідити його елементи.

Результати дослідження. Основним нормативно-правовим актом, який закріплює правовий статус споживача, $є$ Закон України «Про захист прав споживачів». Споживачем за цим законом визнається фізична особа, яка придбаває, замовляє, використовує або має намір придбати чи замовити продукцію для особистих потреб, безпосередньо не пов'язаних із підприємницькою діяльністю або виконанням обов'язків найманого працівника. Із цього визначення випливає, що споживачами можуть бути лише фізичні особи, включаючи громадян України, іноземців та осіб без громадянства. Натомість при застосуванні норм споживчого закону юридичні особи не можуть бути зараховані до категорії споживачів. Окрім того, Закон України «Про захист прав споживачів» не застосовується, якщо фізична особа має статус підприємця і купує, замовляє або 
використовує товари (роботи, послуги) для ведення підприємницької діяльності. Як споживача Закон України «Про захист прав споживачів» визнає і фізичну особу, яка тільки має намір придбати товар чи замовити роботу або послугу.

Таким чином, споживач - це фізична особа, в тому числі фізична особа-підприємець, яка придбаває (набуває іншим чином у власність або у користування) чи замовляє товари (роботи, послуги) або має намір придбати (набути іншим чином у власність або користування) чи замовити товари (роботи, послуги) для особистих або інших потреб, не пов'язаних із підприємницькою діяльністю.

Правовідносини, в яких споживач бере безпосередню участь, є «цивільними правовідносинами за участю споживача», оскільки важко стверджувати про існування кримінальних, адміністративних, екологічних і інші публічних правовідносин за участю споживача, бо останній не $\epsilon$ безпосереднім їх учасником. Правовідносини, в яких споживач бере безпосередню участь (роздрібна купівля-продаж, побутовий підряд, прокат, надання послуг тощо), мають цивільно-правову природу $[9$, с. 180$]$.

Правове становище споживача як основного учасника правовідносин, що виникають на ринку товарів, робіт, послуг у наукових дослідженнях, як правило, розкривають через поняття «правовий статус», яке вказує на роль, місце і значення суб'єкта в суспільстві, його можливості, принципи взаємовідносин з іншими суб'єктами і державою.

Як зазначає О.В. Зайчук, правовий статус як юридична категорія не лише визначає стандарти можливої та необхідної поведінки, що забезпечують нормальну життєдіяльність соціального середовища, а й характеризують реальну взаємодію держави та особи [10]. В.О. Котюк під правовим статусом особи розуміє сукупність юридичних прав, свобод та обов'язків, які закріплені в чинному законодавстві й становлять соціально допустимі та необхідні потенційні можливості особи мати суб'єктивні права й обов'язки, реалізувати їх у системі суспільних відносин [11, с. 100-102]. Л.А. Луць правовий статус особи визначає як закріплені у відповідних джерелах права й гарантовані державою суб'єктивні права та юридичні обов'язки особи $[12$, с. 124$]$. П.М. Рабінович визначає правовий статус особи як комплекс її суб' єктивних юридичних прав та обов'язків [13, с.84]. Порівнюючи різні дефініції поняття «правовий статус особи», можна зробити висновок, що його сутнісною характеристикою $є$ комплекс суб'єктивних юридичних прав та обов'язків.

Багатогранність наукових уявлень про правову природу категорії «правовий статус» активно використовується в дослідженнях, в тому числі і цивільно-правового характеру, що дає змогу констатувати універсальність цієї категорії для характеристики окремого суб'єкта цивільних правовідносин.

Нами сприйнято концепцію, відповідно до якої одному суб’єкту права притаманні всі види статусів: загальний, спеціальний та індивідуальний. Вони нашаровуються один на одного i $\epsilon$ неділимими. Загальний правовий статус у всіх громадян - один, спеціальних статусів (різноманітних) - багато, індивідуальних - стільки, скільки осіб проживає в державі. Правове становище конкретної фізичної особи може розглядатися як сума загального, спеціального та індивідуального статусів, співвідношення яких варіюється залежно від конкретних ситуацій [14, с. 382].

Якщо розглядати правовий статус споживача як частину правового статусу фізичної особи, то він буде спеціальним правовим статусом, оскільки як споживач фізична особа набуває додаткових прав та переваг. Тобто правовий статус споживача $\epsilon$ конкретним проявом загального правового статусу фізичної особи. Спеціальний правовий статус споживача $є$ необхідним як засіб підсилення гарантій його прав і подолання його економічної і правової нерівності із підприємцем.

Спеціальний правовий статус споживача є невід’ємною частиною загального правового статусу, який визначається нормами права. Спеціальний правовий статус споживача - це сукупність прав та обов'язків, які закріплені законодавством про захист прав споживачів, а також гарантій здійснення цих прав шляхом встановлення особливого цивільно-правового механізму їх захисту. Адже споживач як учасник цивільних правовідносин наділений не тільки правами, але і обов'язками, які він має виконувати. Додаткові або, інакше кажучи, спеціальні права, перш за все, на захист надаються споживачеві у разі порушення його права і він не має використовувати ïх на шкоду своєму контрагенту. Саме тому розуміти під правовим статусом споживача тільки систему особливих можливостей, які надані йому правом, або розглядати його тільки як особливе правове становище особи видається не зовсім вірним. Сутність спеціального правового статусу споживача полягає саме в доповненні чи конкретизації прав та обов'язків, яке зумовлено наявністю в особи специфічних рис її становища в суспільстві. 
Аналізуючи права споживача як елемент його правового статусу, доцільно взяти за основу їх поділ на універсальні та спеціальні, запропонований О.Ю. Черняк [5, с. 68]. Універсальні права споживачів характерні для усіх форм участі споживача в цивільно-правових відносинах, а спеціальні - це права споживача при купівлі товарів, права споживача при виконанні робіт, наданні послуг.

Так, до універсальних прав споживачів належать права, закріплені в Розділі II Закону України «Про захист прав споживачів» [1].

Зокрема, відповідно до ч. 1 ст. 4 Закону України «Про захист прав споживачів», споживачі під час придбання, замовлення або використання продукції, яка реалізується на території України, для задоволення своїх особистих потреб мають:

1) право на захист своїх прав державою. Це право конкретизується через встановлення законодавством (ст. 5 Закону України «Про захист прав споживачів») обов'язків держави щодо захисту прав споживачів. Так, держава забезпечує споживачам захист їхніх прав, надає змогу вільно вибирати продукцію, здобувати знання і кваліфікацію, необхідні для прийняття самостійних рішень під час придбання та використання продукції відповідно до їхніх потреб, і гарантує придбання або одержання продукції іншими законними способами в обсязі, що забезпечує рівень споживання, достатній для підтримання здоров'я і життєдіяльності. Держава створює умови для отримання споживачами потрібних знань із питань реалізації їхніх прав;

2) право на належну якість продукції та обслуговування. Згідно з ч. 1 ст. 6 виконавець зобов'язаний передати споживачеві продукцію належної якості, а також надати інформацію про цю продукцію. Держава бере на себе обов'язок встановлювати певні вимоги щодо якості. Це здійснюється шляхом прийняття відповідних законів, створення відповідних органів із контролю за якістю товарів (робіт, послуг) та захисту прав потерпілих;

3) право на безпеку продукції. Це право споживачів конкретизується в ст. 14 Закону України «Про захист прав споживачів». Споживач має право на те, щоб продукція за звичайних умов iï використання, зберігання і транспортування була безпечною для його життя, здоров'я, навколишнього природного середовища, а також не завдавала шкоди його майну;

4) право на необхідну, доступну, достовірну та своєчасну інформацію державною мовою про продукцію, iï кількість, якість, асортимент, її виробника (виконавця, продавця) відповідно до Закону України «Про забезпечення функціонування української мови як державної». Не вдаючись у детальну характеристику права споживача на інформацію, зазначимо тільки, що інформація про продукцію (роботу, послугу) має забезпечити можливість свідомого та компетентного ії вибору споживачем, а також має бути надана до придбання ним товару чи замовлення роботи (послуги);

5) право на обслуговування державною мовою відповідно до Закону України «Про забезпечення функціонування української мови як державної»;

6) право на відшкодування шкоди (збитків), завданих дефектною чи фальсифікованою продукцією або продукцією неналежної якості, а також майнової та моральної (немайнової) шкоди, заподіяної небезпечною для життя і здоров’я людей продукцією у випадках, передбачених законодавством;

7) право на звернення до суду та інших уповноважених органів державної влади за захистом порушених прав. Це право споживачам забезпечується шляхом надання їм додаткових гарантій. Так, споживачі звільняються від сплати державного мита за позовами, що пов'язані 3 порушенням їхніх прав (ч. 3 ст. 22 Закону України «Про захист прав споживачів»), а цивільно-процесуальне законодавство надає їм змогу вибрати підсудність;

8) право на об'єднання в громадські організації споживачів (об'єднання споживачів) (ст. 24 Закону України «Про захист прав споживачів»). Об'єднання споживачів є громадськими організаціями, що здійснюють свою діяльність відповідно до Закону України «Про громадські об'єднання».

Окрім прав, елементом правового статусу споживача $є$ і обов'язки, які також можна класифікувати як універсальні та спеціальні. Відповідно, універсальні обов'язки споживача передбачені ч. 3 ст. 4 Закону України «Про захист прав споживачів». До них належать такі:

1) перед початком експлуатації товару уважно ознайомитися з правилами експлуатації, викладеними в наданій виробником (продавцем, виконавцем) документації на товар;

2) в разі необхідності роз'яснення умов та правил використання товару - до початку використання товару звернутися за роз'ясненнями до продавця (виробника, виконавця) або до іншої вказаної в експлуатаційній документації особи, що виконує їхні функції;

3) користуватися товаром згідно з його цільовим призначенням та дотримуватися умов (вимог, норм, правил), встановлених виробником товару (виконавцем) в експлуатаційній документації; 
4) з метою запобігання негативним для споживача наслідкам використання товару застосовувати передбачені виробником у товарі засоби безпеки з дотриманням передбачених експлуатаційною документацією спеціальних правил, а в разі відсутності таких правил у документаціїдотримуватися звичайних розумних заходів безпеки, встановлених для товарів такого роду.

Внаслідок визнання за споживачем спеціального правового статусу виникає логічне питання щодо наявності в нього спеціальної правосуб'єктності.

О.Ю. Черняк, досліджуючи правовий статус споживача, доходить висновку, що елементом змісту спеціального правового статусу споживача є його спеціальна правосуб'єктність, яку «можна визначити як передбачену нормами цивільного права здатність мати та здійснювати спеціальні права та виконувати обов'язки особливого учасника цивільних правовідносин - споживача» [5, с. 61].

Вважаємо, що теза про наявність у споживача спеціальної правосуб'єктності (спеціальної право- та дієздатності) є недостатньо обгрунтованою, оскільки завдяки спеціальному правовому статусу споживач зберігає свою загальну правосуб'єктність. Суть полягає в тому, що будьяка фізична особа володіє всіма правами споживача, які об'єктивно закріплені в законодавстві, незалежно від набуття нею спеціального статусу. Адже сутність спеціального статусу полягає не у виключенні яких-небудь прав та обов'язків із загальної їх сукупності, а в їх доповненні чи/ або конкретизації, що зумовлено наявністю в особи специфічних рис іiї становища в суспільстві. Правосуб'єктність споживача не залежить ані від характеру суб'єктивних прав та обов'язків, ані від властивостей правовідносин, в яких вона реалізується. Окрім цього, якщо, наприклад, правосуб'єктність підприємця в рамках досліджуваних правовідносин може взаємодіяти з його правосуб'єктністю іншої галузевої приналежності, то на правосуб'єктність споживача нічого не впливає, окрім загальних обмежень, передбачених цивільним законодавством.

Висновки. Підсумовуючи наведене вище, варто зазначити, що споживачеві як учаснику цивільних правовідносин притаманний спеціальний правовий статус, оскільки як споживач фізична особа набуває додаткових прав та переваг. Спеціальний правовий статус споживача $є$ невід’ємною частиною загального правового статусу, який визначається нормами права. Спеціальний правовий статус споживача - це сукупність прав та обов'язків, які закріплені законодавством про захист прав споживачів, а також гарантій здійснення цих прав шляхом встановлення особливого цивільно-правового механізму їх захисту. Як учасник цивільних правовідносин споживач наділений спеціальними правами та обов'язками, які можна класифікувати як універсальні (загальні) та спеціальні. Універсальні права та обов'язки споживачів характерні для усіх форм участі споживача у цивільно-правових відносинах, а спеціальні - це права та обов'язки споживача при купівлі товарів, права споживача при виконанні робіт, наданні послуг. Однак, незважаючи на те, що цивільно-правовий статус фізичної особи-споживача розширений за рахунок додаткових (спеціальних) прав та обов'язків, йому не притаманна спеціальна правосуб'єктність.

\section{Список використаних джерел:}

1. Про захист прав споживачів : Закон України від 12.05.1991 р. № 1023-XII. URL: http://zakon1.rada.gov.ua/laws/show/1023-12.

2. Гудима М.М. Захист прав споживачів за договором про надання туристичних послуг : дис. ... канд. юрид. наук : 12.00.03 / ДВНЗ «Прикарпатський національний університет ім. Василя Стефаника. Івано-Франківськ, 2013. 212 с.

3. Осетинська Г.А. Цивільно-правовий захист прав споживачів за законодавством України : автореф. дис. ... канд. юрид. наук : 12.00 .03 / Київський національний університет ім. Тараса Шевченка. Київ, 2006. 20 с.

4. Рябченко Ю.Ю. Судовий захист прав споживачів : автореф. дис. ... канд. юрид. наук : 12.00.03/НДІ приватного права іпідприємництва ім. Ф.Г. Бурчака НАПрН України. Київ, 2009. 19 с.

5. Черняк О.Ю. Цивільно-правовий статус споживача у контексті адаптації законодавства України до законодавства Європейського Союзу : дис. ... канд. юрид. наук : 12.00 .03 / НДІ приватного права і підприємництва ім. Ф.Г. Бурчака НАПрН України. Київ, 2011. 230 с.

6. Єгоричева О.Ю. Цивільно-правова відповідальність за продаж споживачам товарів неналежної якості : автореф. дис. ... канд. юрид. наук : 12.00 .03 / НДІ приватного права і підприємництва ім. Ф.Г. Бурчака НАПрН України. Київ, 2014. 20 с.

7. Ільченко Г.О. Цивільно-правовий захист прав споживачів страхових послуг : автореф. дис. ... канд. юрид. наук : 12.00 .03 / НДІ приватного права і підприємництва ім. Ф.Г. Бурчака НАПрН України. Київ, 2016. 20 с. 
8. Гришко У.П. Захист прав споживачів транспортних послуг : автореф. дис. ... канд. юрид. наук : 12.00.03 / ДВНЗ «Прикарпатський національний університет ім. В. Стефаника». Івано-Франківськ, 2017. 19 с.

9. Банасевич I.I. Поняття та сутність правовідносин за участю споживачів. Юридичний бюлетень: наук. журнал. 2018. № 7 (7). Ч. 1. С. 177-182.

10. Зайчук О.В., Оніщенко Н.М. Теорія держави і права. Академічний курс. Підручник. Київ : Юрінком Інтер, 2006. URL: http://ebk.net.ua/Book/law/zaychuk_tdp/part2/402.htm/.

11. Котюк В.О. Теорія права: Навчальний посібник для юрид. фак. Київ : Вентурі, 1996. 208 с.

12. Луць Л.А. Загальна теорія держави і права : Навчально-методичний посібник (за кредитно-модульною системою). Київ : Атіка, 2007. 412 с..

13. Рабінович П.М. Основи загальної теорії права та держави : навчальний посібник. 9-е вид., зі змінами. Львів : Край, 2007. 188 с.

14. Скакун О.Ф. Теорія держави і права : Підручник. Харків : Консум, 2001. 656 с.

УДК 347.453

DOI https://doi.org/10.32844/2618-1258.2019.5-1.8

ГАБРІАДЗЕ М.Р.

\section{ПРАВОВЕ РЕГУЛЮВАННЯ ДОГОВОРУ ЛІЗИНГУ ЗА ЦИВІЛЬНИМ ЗАКОНОДАВСТВОМ УКРАЇНИ}

Статтю присвячено дослідженню окремих аспектів правового регулювання договору лізингу за цивільним законодавством України, його міжгалузевим зв'язкам iз господарським правом, підприємницькою діяльністю та регулюванню окремих питань цивільно-правових відносин відповідно до Закону України «Про фінансовий лізинг».

На початку статті логічно розглянуто поняття «договір» відповідно до Цивільного кодексу України та надано погляди науковців на поняття «договір». На підставі викладеного зазначено, що поняття «договір» у Цивільному кодексі України $\epsilon$ більш логічним та зрозумілим, ніж більшість визначень, які надають фахівці в галузі цивільного права.

Проблемним питанням, що розглядається в науковій статті, є саме поняття «лізинг». У визначенні поняття «лізинг» $є$ те, що в більшості досліджень, присвячених лізингу, припускається вибір одного з відомих підходів у використанні терміна «лізинг», але під час тлумачення терміна «лізинг» існують значні відмінності в описанні «лізингу» як економічних, господарських або інвестиційних відносин, і складається враження про велику кількість форм одного і того ж по суті явища, тому є підтвердження та існування одночасно двох понять на рівні законодавства, а саме «лізинг» та «фінансовий лізинг».

Основна частина статті присвячена правовому регулюванню договору лізингу за цивільним законодавством України, а саме питанням про істотні умови договору лізингу, строки договору лізингу, предмет договору лізингу та питанню про суб'єкти договору лізингу, їх права та обов'язки. Автор наголошує, що лізинг - це цивільно-правові відносини, які врегульовані главою 58 ЦК України та Законом України «Про фінансовий лізинг» і мають таку побудову: по-перше, лізингодавець та лізингоодержувач укладають договір фінансового лізингу, в якому зумовлюються істотні умови договору; по-друге, між лізингодавцем та продавцем (постачальником) укладається договір купівлі-продажу або поставки, відповідно до якого

(C) ГАБРІАДЗЕ М.Р. - кандидат юридичних наук, доцент кафедри конституційного, міжнародного та приватного права (Криворізький факультет Національного університету «Одеська юридична академія») 